\title{
Pola menonton televisi sebagai faktor risiko obesitas pada anak di sekolah dasar Kota Yogyakarta dan Kabupaten Bantul
}

Dewi Astiti', Hamam Hadi², Madarina Julia ${ }^{3}$

\begin{abstract}
Background: Obesity in Indonesian school children is increasing dramatically especially in the cities. Whether TV viewing has an important role to the increased obesity prevalence Indonesia is still unclear.

Objective: To examine TV viewing as a risk factor of obesity in Indonesian elementary school children.

Method: A case-control study of 244 obese and 244 non obese children was conducted in Yogyakarta municipality in 2012. Cases were elementary school children with BMI/Age $>95^{\text {th }}$ percentile identified in previous survey. Controls were children from the same class and seating at the right side nearest to the cases. Weight of the children was measured using a calibrated digital weighing scale (SECA) with precision of $0.1 \mathrm{~kg}$, while standing height was measured using a microtoice with precision of $0.1 \mathrm{~cm}$ by trained nutritionists. Data on TV viewing were collected using one-week physical activity recall questionnaires. BMI of the study subjects were computed using WHO Anthro2005 software. Statistical analysis was done using STATA $11^{\text {th }}$ edition software.

Result: Children with TV viewing $\geq 2$ hours/day were $3(\mathrm{OR}=3.3,95 \% \mathrm{Cl}$ : 2.2-4.8) times more likely to be obese than children with TV viewing $<2$ hours/day. Parental regulation of tv viewing was associated with child's TV viewing duration.

Conclusion: Duration of TV viewing was significantly associated with the increased risk of obesity in elementary school children. The existence of parental regulation would help to reduce TV viewing duration leading to the reduction of obesity prevalence in school children.
\end{abstract}

KEYWORDS: obesity, elementary school children, TV viewing

\begin{abstract}
ABSTRAK
Latar Belakang: Obesitas pada anak-anak sekolah Indonesia meningkat sangat drastis terutama di kota-kota. Apakah menonton TV memiliki peran penting terhadap peningkatan prevalensi obesitas Indonesia masih belum jelas.

Tujuan: Untuk menguji menonton TV sebagai faktor risiko obesitas pada anak-anak sekolah dasar di Indonesia.

Metode: Sebuah studi kasus-kontrol dari 244 obesitas dan 244 anak non obesitas dilakukan di Kota Yogyakarta pada tahun 2012. Kasus adalah anak-anak SD dengan BMI/Umur >persentil ke-95 diidentifikasi dalam survei sebelumnya. Kontrol adalah anak-anak dari kelas yang sama dan duduk di sisi kanan terdekat dengan kasus. Berat anak-anak diukur dengan menggunakan timbangan digital (SECA) yang telah dikalibrasi dengan presisi 0,1 kg, sedangkan tinggi berdiri diukur dengan menggunakan microtoice dengan presisi $0,1 \mathrm{~cm}$ oleh ahli gizi terlatih. Data menonton TV dikumpulkan menggunakan kuesioner aktivitas fisik selama satu minggu. BMI dari subjek penelitian dihitung dengan menggunakan software WHO Anthro 2005. Analisis statistik dilakukan dengan menggunakan perangkat lunak STATA edisi 11.

Hasil: Anak-anak yang menonton TV $\geq 2$ jam / hari cenderung 3 (OR = 3,3, 95\% Cl: 2,2-4,8) kali lebih gemuk daripada anak-anak dengan menonton TV $<2$ jam/hari. Peraturan orangtua menonton TV dikaitkan dengan durasi menonton TV anak

Kesimpulan: Durasi menonton TV secara bermakna dikaitkan dengan peningkatan risiko obesitas pada anak-anak sekolah dasar. Adanya peraturan orangtua akan membantu mengurangi durasi menonton TV yang mengarah ke pengurangan prevalensi obesitas pada anak-anak sekolah.
\end{abstract}

KATA KUNCI: obesitas, anak-anak SD, menonton TV

\footnotetext{
1 Sekolah Tinggi Ilmu Kesehatan Alma Ata Yogyakarta. Jl.Ringroad Barat Daya No. 1, Tamantirto, Yogyakarta, Telp (0274) 4342288, 4342270 e-mail: dewi.astiti@gmail.com

${ }^{2}$ Magister Gizi dan Kesehatan Fakultas Kedokteran Universitas Gadjah Mada, Jl. Farmako, Sekip Utara Yogyakarta 55281, e-mail:hamamhadi99@ gmail.com

3 Instalasi Kesehatan Anak RSUP Dr. Sardjito, Jl. Kesehatan, Yogyakarta 55281, e-mail: madarinajulia@yahoo.com
} 


\section{PENDAHULUAN}

Kegemukan dan obesitas telah menjadi masalah kesehatan global di dunia baik di negara maju seperti negara-negara di Eropa dan Amerika maupun di negara berkembang seperti di Asia dan Afrika (1). Prevalensi obeistas di Provinsi Daerah Istimewa Yogyakarta menurut data Riskesdas tahun 2007 menunjukkan prevalensi berat badan lebih berdasarkan kategori IMT/U (Z score $>2)$ pada anak usia 6-14 tahun adalah 7,6\% pada anak laki-laki dan $4,8 \%$ pada anak perempuan (2). Hasil Riskesdas thun 2010 menunjukkan bahwa prevalensi obesitas pada anak usia 6-12 tahun adalah 7,8\% secara keseluruhan pada anak laki-laki dan perempuan (3).

Prevalensi obesitas ini dipacu oleh tingginya peredaran makanan yang tinggi kandungan lemak, minyak dan karbohidrat, kemudahan yang diberikan oleh teknologi, serta gaya hidup yang kurang aktivitas fisik termasuk aktivitas berbasis layar (1). Durasi dan frekuensi penggunaan media berbasis layar (televisi, video game dan komputer) dinyatakan sebagai salah satu penyebab rendahnya aktivitas fisik anakanak (4). Anak-anak yang mempunyai aktivitas berbasis layar lebih panjang dilaporkan mempunyai risiko lebih tinggi untuk mengalami obes dibandingkan anak dengan aktivitas berbasis layar lebih rendah (5). Di samping itu, aktivitas berbasis layar lebih pada anak-anak berkaitan dengan meningkatkan keterpaparan anak pada iklan makanan di televisi yang dapat mempengaruhi pola makan mereka $(6,7)$. Oleh karena itu, American Academy of Pediatrics (AAP) telah mengeluarkan rekomendasi agar durasi penggunaan media berbasis layar bagi anak-anak tidak lebih dari 1 hingga 2 jam per hari (4). Panjangnya durasi menonton TV pada anak ini dilaporkan berkaitan dengan ketersediaan TV set di dalam kamar tidur anak (8) dan ada atau tidak adanya peraturan orang tua untuk menonton TV dalam kehidupan sehari-hari (5). Namun demikian, hubungan antara aktivitas berbasis layar dan obesitas, begitu juga hubungannya dengan tingginya paparan iklan makanan pada anak-anak Indonesia belum diketahui. Oleh karena itu, peneliti tertarik untuk melakukan penelitian dan mendeskripsikan pola menonton anak sekolah dasar, durasi menonton TV, dan besar risiko durasi menonton TV terhadap kejadian obesitas pada anak di sekolah dasar Kota Yogyakarta dan Kabupaten Bantul.

\section{BAHAN DAN METODE}

Penelitian ini adalah penelitian obeservasional dengan rancangan kasus kontrol. Kasus dan kontrol diambil dari survei sebelumnya yang melibatkan 3.483 siswa dari 32 sekolah dasar di Kota Yogyakarta dan 35 sekolah dasar di Kabupaten Bantul yang dipilih menggunakan metode probability proportional to size (PPS) dan dengan tingkatan kelas sebagai klasternya. Sebanyak 224 anak sekolah dasar di Kota Yogyakarta dan Kabupaten Bantul yang dinyatakan obes yaitu anak-anak yang mempunyai nilai indeks massa tubuh (IMT) menurut umur $>95$ persentil dipilih secara acak sederhana dari seluruh anak yang teridentifikasi obesitas pada survei tersebut. Setiap kasus yang terpilih dicarikan kontrol pasangannya yaitu anak sekolah dasar yang tidak overweight dan tidak obes yang duduk paling dekat disebelah kanan kasus. Penelitian ini telah mendapatkan persetujuan dan kelaikan penelitian dari Komite Etik Fakultas Kedokteran UGM tanggal 15 Maret 2013 Ref: KE/FK/249/EC.

Informasi karakteristik subjek, status sosial ekonomi, dan pola menonton TV pada anak dikumpulkan menggunakan kuesioner terstruktur yang dilengkapi dengan 7 hari recall 24 jam aktivitas fisik. Tinggi badan anak diukur dengan menggunakan microtoise dan berat badan anak diukur dengan timbangan badan elektonik/ electronic personal scale). Uji coba kuesioner dan recall aktivitas dilakukan pada 30 siswa sekolah dasar di Kabupaten Sleman untuk menguji kemudahan kuesioner dipahami dan dijawab oleh responden serta pencapaian kebutuhan data penelitian. Pengambilan data penelitian dibantu oleh tenaga enumerator mahasiswa dan lulusan gizi yang telah dilatih untuk menggunakan instrumen penelitian. Analisis data dilakukan dengan uji Chi Square, t-test, dan regresi logistik.

\section{HASIL}

\section{Karakteristik subjek penelitian}

Secara keseluruhan, karakteristik kasus hampir sama dengan kontrol. Tidak ada perbedaan bermakna antara kasus dan kontrol menurut usia anak, pendidikan dan pekerjaan ibu, pendidikan dan pekerjaan ayah, penghasilan keluarga dan jumlah anak yang menjadi tanggungan keluarga. Akan tetapi kasus berbeda bermakna dengan kontrol menurut jenis kelamin $(p<0,05)$. Dalam penelitian ini, jumlah kasus laki-laki 13\% lebih besar dibandingkan kontrol laki-laki (Tabel 1).

\section{Stasiun TV dan program acara favorit anak}

Tiga stasiun TV yang paling banyak menayangkan acara kartun dan sinetron merupakan stasiun TV yang paling digemari oleh anak pada kelompok kasus dan kontrol. Preferensi stasiun TV dari anak sekolah dasar di Kota Yogyakarta dan Kabupaten Bantul juga terlihat sama. Begitu pula dengan program acara televisi yang paling mereka sukai, yakni kartun dan sinetron (data tidak ditunjukkan).

Karakteristik responden yang terkait dengan TV dan kebiasaan menonton TV, hanya variable peraturan orang tua dan frekuensi makan malam sambil menonton TV yang menunjukkan perbedaan bermakna antara kelompok obes dan kelompok tidak obes (Tabel 2). 
Tabel 1. Karakteristik subjek penelitian

\begin{tabular}{|c|c|c|c|c|c|}
\hline Karakteristik & $\begin{array}{c}\text { Obes }(n=244) \\
n(\%)\end{array}$ & $\begin{array}{c}\text { Tidak obes }(n=244) \\
n(\%)\end{array}$ & $\begin{array}{c}\text { Total } \\
(\mathrm{n}=488)\end{array}$ & $\chi^{2}$ & $\mathbf{p}$ \\
\hline \multicolumn{6}{|l|}{ Jenis kelamin } \\
\hline Laki-laki & $154(63,11)$ & $122(50)$ & 276 & 8,54 & $0,003^{*}$ \\
\hline Perempuan & $90(36,89)$ & $122(50)$ & 212 & & \\
\hline \multicolumn{6}{|l|}{ Kategori wilayah } \\
\hline Yogyakarta & $166(68,03)$ & $166(68,03)$ & 332 & 0,00 & 1,00 \\
\hline Bantul & $78(31,97)$ & $78(31,97)$ & 156 & & \\
\hline \multicolumn{6}{|l|}{ Kelompok usia } \\
\hline 6-8 tahun & $84(34,43)$ & $83(34,02)$ & 167 & 0,29 & 0,86 \\
\hline 9-10 tahun & $114(46,72)$ & $119(48,77)$ & 233 & & \\
\hline 11-12 tahun & $46(18,85)$ & $42(17,21)$ & 88 & & \\
\hline \multicolumn{6}{|l|}{ Pendidikan ibu } \\
\hline Tinggi (>SMP) & $200(81,97)$ & $191(78,28)$ & 391 & 1,04 & 0,31 \\
\hline Rendah ( $\leq$ SMP) & $44(18,03)$ & $53(21,72)$ & 97 & & \\
\hline \multicolumn{6}{|l|}{ Pekerjaan ibu } \\
\hline Tidak bekerja & $64(26,23)$ & $57(23,26)$ & 121 & 0,54 & 0,46 \\
\hline Bekerja & $180(73,77)$ & $187(76,64)$ & 367 & & \\
\hline \multicolumn{6}{|l|}{ Pendidikan ayah } \\
\hline Tinggi (> SMP) & $208(85,25)$ & $200(81,97)$ & 408 & 0,95 & 0,33 \\
\hline Rendah ( $\leq$ SMP) & $36(14,75)$ & $44(18,03)$ & 80 & & \\
\hline \multicolumn{6}{|l|}{ Pekerjaan ayah } \\
\hline Petani/peternak/nelayan & $2(0,83)$ & $3(1,24)$ & 5 & 7,16 & 0,31 \\
\hline Buruh/buruh tani & $21(8,68)$ & $36(14,88)$ & 57 & & \\
\hline Karyawan swasta & $70(28,93)$ & $71(29,34)$ & 141 & & \\
\hline PNS/TNI/POLRI & $39(16,12)$ & $31(12,81)$ & 70 & & \\
\hline Wiraswasta & $93(38,43)$ & $80(33,06)$ & 173 & & \\
\hline Tidak bekerja & $1(0,41)$ & $3(1,24)$ & 4 & & \\
\hline Lainnya & $16(6,61)$ & $18(7,44)$ & 34 & & \\
\hline \multicolumn{6}{|l|}{ Pengeluaran rumah tangga } \\
\hline$\leq$ Rp. 1.000 .000 & $20(47,62)$ & $22(52,38)$ & 42 & 0,10 & 0,75 \\
\hline > Rp.1.000.000 & $224(50,22)$ & $222(49,78)$ & 446 & & \\
\hline \multicolumn{6}{|l|}{ Jumlah ART } \\
\hline$\leq 4$ orang & $149(61,07)$ & $145(59,43)$ & 293 & 0,14 & 0,71 \\
\hline$>4$ orang & $95(38,93)$ & $99(40,57)$ & 195 & & \\
\hline
\end{tabular}

*Bermakna $(p<0,05)$

\section{Waktu puncak dan durasi menonton TV}

Dalam penelitian ini, ditemukan waktu puncak menonton TV tidak berbeda antara anak obes dan anak tidak obes $(p>0,05)$. Anak-anak baik yang obes maupun tidak obes pada umumnya menonton TV di pagi, siang, maupun malam hari. Namun demikian, anak-anak yang obes memiliki rata-rata durasi menonton TV yang lebih lama di seluruh segmen waktu dalam sehari, baik pada hari sekolah (weekdays) maupun di akhir pekan (weekend). Pagi hari weekdays adalah segmen waktu dengan paling sedikit anak, baik dalam kelompok obes maupun tidak obes yang melakukan aktivitas menonton TV, serta ratarata durasi menonton TV yang paling pendek pula yakni $17,49 \pm 17,64$ menit pada anak obes dan $14,77 \pm 15,00$ menit pada anak tidak obes. Segmen waktu malam hingga tidur pada hari sekolah merupakan waktu puncak menonton TV pada anak. Rata-rata durasi menonton TV dalam segmen waktu tersebut adalah $56,27 \pm 33,17$ menit pada anak obes dan 50,54 $\pm 33,74$ menit pada anak tidak obes (Gambar 1 dan Tabel 3).
Segmen waktu magrib hingga tidur malam adalah waktu puncak menonton TV pada hari Sabtu, sedangkan pada hari Minggu, waktu puncak menonton TV adalah pagi hingga siang hari dengan rata-rata durasi 107,41 $\pm 54,49$ menit pada anak obes dan 93,66 $\pm 51,43$ menit pada anak tidak obes (Gambar 1 dan Tabel 3).

Penelitian ini membuktikan bahwa terdapat perbedaan bermakna antara rata-rata durasi menonton

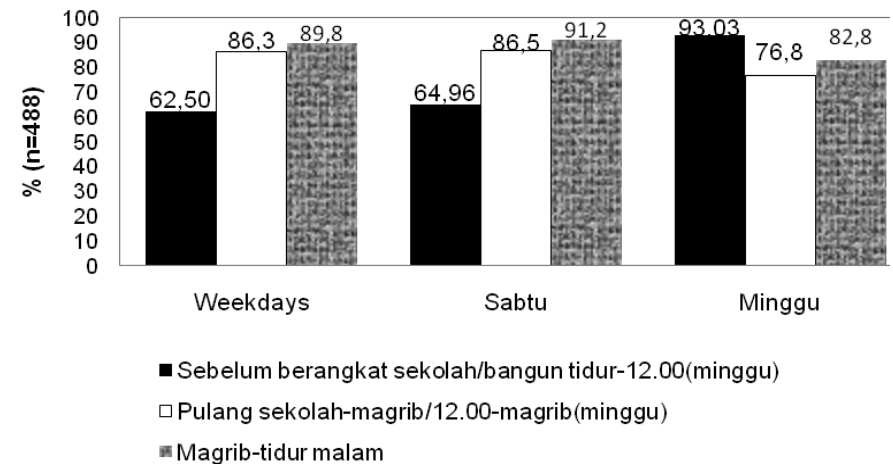

Gambar 1. Waktu puncak menonton TV pada anak 
Tabel 2. Karakteristik responden

\begin{tabular}{|c|c|c|c|c|c|}
\hline Karakteristik & $\begin{array}{c}\text { Obes }(n=244) \\
n(\%)\end{array}$ & $\begin{array}{c}\text { Tidak obes }(n=244) \\
n(\%)\end{array}$ & Total $(n=488)$ & $\chi^{2}$ & $\mathbf{p}$ \\
\hline \multicolumn{6}{|l|}{ Jumlah TV } \\
\hline$>2$ unit & $49(20,08)$ & $36(14,75)$ & 85 & \multirow[t]{2}{*}{2,40} & \multirow[t]{2}{*}{0,12} \\
\hline$\leq 2$ unit & $195(79,92)$ & $208(85,25)$ & 403 & & \\
\hline \multicolumn{6}{|l|}{ TV dalam kamar tidur } \\
\hline $\mathrm{Ya}$ & $85(34,84)$ & $68(27,87)$ & 153 & \multirow[t]{2}{*}{2,75} & \multirow[t]{2}{*}{0,10} \\
\hline Tidak & $159(65,16)$ & $176(72,13)$ & 335 & & \\
\hline \multicolumn{6}{|l|}{ Peraturan orangtua } \\
\hline $\mathrm{Ya}$ & $147(60,25)$ & $170(69,67)$ & 317 & \multirow[t]{2}{*}{4,76} & \multirow[t]{2}{*}{$0,029^{*}$} \\
\hline Tidak & $97(39,75)$ & $74(30,33)$ & 171 & & \\
\hline \multicolumn{6}{|l|}{ Pendampingan orangtua } \\
\hline $\mathrm{Ya}$ & $112(45,90)$ & $114(46,72)$ & 226 & \multirow[t]{2}{*}{0,03} & \multirow[t]{2}{*}{0,86} \\
\hline Tidak & $132(54,10)$ & $130(53,28)$ & 262 & & \\
\hline \multicolumn{6}{|l|}{ Makan saat menonton TV } \\
\hline $\mathrm{Ya}$ & $201(82,38)$ & $204(83,61)$ & 405 & \multirow[t]{2}{*}{0,13} & \multirow[t]{2}{*}{0,72} \\
\hline Tidak & $43(17,62)$ & $40(16,39)$ & 83 & & \\
\hline \multicolumn{6}{|l|}{ Nonton TV saat sarapan } \\
\hline Setiap hari & $64(26,23)$ & $43(17,62)$ & 107 & \multirow[t]{4}{*}{7,17} & \multirow[t]{4}{*}{0,07} \\
\hline $4-6 x$ seminggu & $31(12,70)$ & $36(14,75)$ & 67 & & \\
\hline $1-3 x$ seminggu & $52(21,31)$ & $70(28,69)$ & 122 & & \\
\hline Tidak pernah & $97(39,75)$ & $95(38,93)$ & 192 & & \\
\hline \multicolumn{6}{|c|}{$\begin{array}{l}\text { Nonton TV saat makan siang } \\
\text { Setiap hari }\end{array}$} \\
\hline 4-6x seminggu & $67(27,46)$ & $49(20,08)$ & 116 & \multirow[t]{4}{*}{5,32} & \multirow[t]{4}{*}{0,10} \\
\hline $1-3 x$ seminggu & $43(17,62)$ & $59(24,18)$ & 102 & & \\
\hline \multirow[t]{2}{*}{ Tidak pernah } & $75(30,74)$ & $76(31,15)$ & 151 & & \\
\hline & $59(24,18)$ & $60(24,59)$ & 119 & & \\
\hline \multirow{2}{*}{\multicolumn{6}{|c|}{$\begin{array}{l}\text { Nonton TV saat makan malam } \\
\text { Setiap hari }\end{array}$}} \\
\hline & & & & & \\
\hline 4-6x seminggu & $70(28,69)$ & $40(16,39)$ & 110 & \multirow[t]{4}{*}{12,97} & \multirow[t]{4}{*}{$0,005^{*}$} \\
\hline $1-3 x$ seminggu & $41(16,80)$ & $62(25,41)$ & 103 & & \\
\hline Tidak pernah & $60(24,59)$ & $68(27,87)$ & 128 & & \\
\hline & $73(29,92)$ & $74(30,33)$ & 147 & & \\
\hline
\end{tabular}

${ }^{*}$ Bermakna $(p<0,05)$

TV dalam sehari pada kelompok obes dan tidak obes (Gambar 2 dan Tabel 4). Durasi menonton TV pada akhir pekan/weekends cenderung lebih tinggi dibandingkan dengan pada hari sekolah/weekdays, baik pada kelompok obes maupun tidak obes dengan perbedaan rata-rata durasi masing-masing mencapai 60 menit atau 1 jam

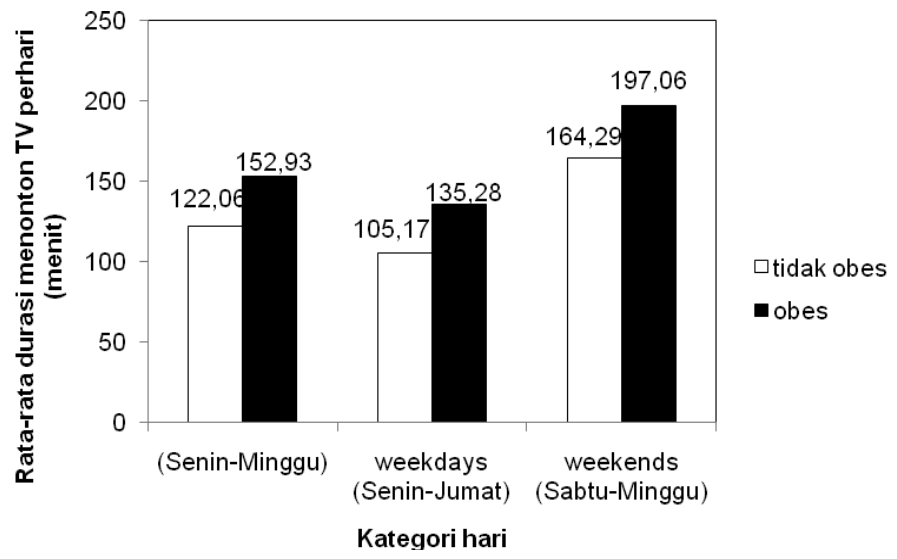

Gambar 2. Rata-rata durasi menonton TV pada anak menurut kategori hari
(Tabel 5). Rata-rata durasi menonton TV pada anak obes di Kabupaten Bantul lebih tinggi hampir 10 menit/ hari dibanding durasi menonton pada anak obes di Kota Yogyakarta, namun perbedaan ini tidak bermakna secara statistik $(p>0,05)$.

\section{Peraturan orang tua dan durasi menonton TV}

Ada tidaknya peraturan orang tua yang mengatur atau membatasi anak untuk menonton TV juga terbukti menjadi faktor yang penting terhadap rata-rata durasi menonton TV. Dalam analisis lebih lanjut ditemukan bahwa secara umum durasi menonton TV 14 menit lebih pendek pada kelompok anak dari keluarga yang mempunyai peraturan menonton TV dibandingkan durasi menonton TV pada kelompok anak dari keluarga yang tidak mempunyai peraturan $(p<0,05)($ Tabel 6$)$.

\section{Durasi menonton TV dan risiko obesitas}

Jika durasi menonton TV dikategorikan menjadi dua kategori sesuai rekomendasi dari American Academy of 
Tabel 3. Waktu puncak menonton TV dan durasi menonton TV berdasarkan segmen waktu

\begin{tabular}{|c|c|c|c|c|c|c|c|c|c|}
\hline \multirow[b]{2}{*}{ Waktu } & \multirow[b]{2}{*}{$\begin{array}{c}n(\%) \\
(n=488)\end{array}$} & \multirow{2}{*}{$\begin{array}{c}\text { Rata-rata } \\
\text { durasi }^{\#} \\
\text { (menit/hari) }^{\text {ment }}\end{array}$} & \multicolumn{2}{|c|}{ Obes $(\mathrm{N}=244)$} & \multicolumn{2}{|c|}{ Tidak obes $(\mathrm{N}=244)$} & \multirow[b]{2}{*}{$\begin{array}{c}\text { Mean } \\
\text { diff }\end{array}$} & \multirow[b]{2}{*}{$95 \% \mathrm{Cl}$} & \multirow[b]{2}{*}{ p } \\
\hline & & & $\mathbf{n}$ & 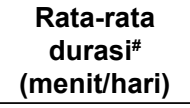 & $\mathbf{n}$ & $\begin{array}{c}\text { Rata-rata } \\
\text { durasi }^{\#} \\
\text { (menit/hari) }^{\text {(mention }}\end{array}$ & & & \\
\hline \multicolumn{10}{|l|}{ Weekdays (Senin-Jumat) } \\
\hline Sebelum berangkat sekolah & $305(62.50)$ & $16,13 \pm 16,42$ & 153 & $17,49 \pm 17,64$ & 152 & $14,77 \pm 15,00$ & 2,72 & $-0,19-5,63$ & 0.03 \\
\hline Pulang sekolah-magrib & $421(86.27)$ & $50,89 \pm 35,91$ & 216 & $58,84 \pm 39,11$ & 205 & $42,93 \pm 30,45$ & 15,91 & $9,68-22,14$ & $0.000^{*}$ \\
\hline Magrib hingga tidur & $438(89.75)$ & $53,41 \pm 33,54$ & 225 & $56,27 \pm 33,17$ & 213 & $50,54 \pm 33,73$ & 5,73 & $-0,22-11,68$ & 0,03 \\
\hline \multicolumn{10}{|l|}{ Sabtu } \\
\hline Sebelum berangkat sekolah & 317 (64.96) & $18,34 \pm 17,3$ & 167 & $19,71 \pm 17,44$ & 150 & $16,96 \pm 17,10$ & 2,74 & $-0,33-5,81$ & 0,04 \\
\hline Pulang sekolah-magrib & $422(86.48)$ & $59,99 \pm 39,86$ & 213 & $65,58 \pm 42,08$ & 209 & $54,40 \pm 36,77$ & 11,18 & $4,15-18,20$ & $0,000^{*}$ \\
\hline Magrib - tidur & 445 (91.19) & $74,30 \pm 45,12$ & 226 & $80,55 \pm 47,61$ & 219 & $68,05 \pm 41,65$ & 12,5 & $4,54-20,46$ & $0,001^{*}$ \\
\hline \multicolumn{10}{|l|}{ Minggu } \\
\hline Bangun tidur-12.00 & $454(93.03)$ & $100,53 \pm 53,37$ & 230 & $107,41 \pm 54,49$ & 224 & $93,66 \pm 51,43$ & 13,75 & $4,32-23,17$ & $0,002^{*}$ \\
\hline 12.00 -magrib & $374(76.80)$ & $54,34 \pm 42,35$ & 193 & $60,24 \pm 44,45$ & 181 & $48,44 \pm 39,37$ & 11,80 & $4,33-19,27$ & $0,001^{*}$ \\
\hline Magrib-tidur & $404(82.79)$ & $54,39 \pm 41,94$ & 213 & $61,88 \pm 40,44$ & 191 & $47,07 \pm 42,17$ & 14,81 & $7,42-22,20$ & $0,000^{*}$ \\
\hline
\end{tabular}

*Bermakna $(p<0,05)$

$\mathrm{n}(\%)=$ jumlah anak yang menonton TV dan persentase terhadap total sampel (n)

Tabel 4. Rata-rata durasi menonton TV

\begin{tabular}{|c|c|c|c|c|c|c|c|c|c|}
\hline & \multirow[b]{2}{*}{$\begin{array}{c}n(\%) \\
(n=488)\end{array}$} & \multirow{2}{*}{$\begin{array}{c}\text { Durasi } \\
\text { (menit/hari) }\end{array}$} & \multicolumn{2}{|c|}{ Obes $(n=244)$} & \multicolumn{2}{|c|}{ Tidak obes $(n=244)$} & \multirow[b]{2}{*}{$\begin{array}{c}\text { Mean } \\
\text { diff }\end{array}$} & \multirow[b]{2}{*}{$95 \% \mathrm{Cl}$} & \multirow[b]{2}{*}{$\mathbf{p}$} \\
\hline & & & $\mathbf{n}$ & $\begin{array}{c}\text { Durasi } \\
\text { (menit/hari) }\end{array}$ & $\mathbf{n}$ & $\begin{array}{c}\text { Durasi } \\
\text { (menit/hari) }\end{array}$ & & & \\
\hline Durasi per hari" & $487(99,79)$ & $137,49 \pm 49,56$ & 244 & $152,93 \pm 49,51$ & 243 & $122,06 \pm 44,56$ & 30,87 & $22,48-39,26$ & $0,000^{*}$ \\
\hline $\begin{array}{l}\text { Durasi per hari weekdays } \\
\text { (Senin - Jumat) }\end{array}$ & $481(98,56)$ & $120,22 \pm 55,23$ & 243 & $135,28 \pm 56,58$ & 238 & $105,17 \pm 49,57$ & 30,11 & $20,65-39,57$ & $0,000^{*}$ \\
\hline $\begin{array}{l}\text { Durasi per hari weekends } \\
\text { (Sabtu - Minggu) }\end{array}$ & $487(99,79)$ & $180,68 \pm 56,73$ & 244 & $197,06 \pm 57,61$ & 243 & $164,29 \pm 50,90$ & 32,76 & $23,09-42,43$ & $0,000^{*}$ \\
\hline
\end{tabular}

*Bermakna $(p<0,05)$

\# durasi/hari adalah rata-rata durasi menonton TV dalam menit yang diperoleh dengan menjumlahkan durasi menonton pada 5 hari weekdays dengan durasi menonton pada 2 hari weekends dan membaginya dengan 7 hari.

Tabel 5. Rata-rata durasi menonton TV pada anak obes dan tidak obes berdasarkan kelompok hari dan wilayah

\begin{tabular}{|c|c|c|c|c|c|c|c|}
\hline $\begin{array}{l}\text { Rata-rata durasi nonton TV } \\
\text { (menit/hari) }\end{array}$ & $\mathbf{n}$ & $\begin{array}{c}\text { Obes } \\
\text { Mean } \pm \text { SD }\end{array}$ & $\mathbf{n}$ & $\begin{array}{l}\text { Tidak obes } \\
\text { Mean } \pm \text { SD }\end{array}$ & $\begin{array}{c}\text { Mean } \\
\text { diff }\end{array}$ & $95 \% \mathrm{Cl}$ & $\mathbf{p}$ \\
\hline \multicolumn{8}{|l|}{ Obes } \\
\hline Weekdays & 244 & $135,28 \pm 56,58$ & - & - & $-61,78$ & $-69,59-(-53,96)$ & $0,000^{*}$ \\
\hline Weekends & 244 & $197,06 \pm 57,61$ & & & & & \\
\hline \multicolumn{8}{|l|}{ Tidak obes } \\
\hline Weekdays & - & - & 244 & $105,17 \pm 49,57$ & $-59,13$ & $-65,38-(-52,88)$ & $0,000^{*}$ \\
\hline Weekends & & & 244 & $164,29 \pm 50,90$ & & & \\
\hline \multicolumn{8}{|l|}{ Lokasi sekolah } \\
\hline Yogyakarta & 166 & $149,86 \pm 49,98$ & 166 & $121,22 \pm 45,98$ & 28,63 & $18,32-38,95$ & $0,000^{*}$ \\
\hline Bantul & 78 & $159,47 \pm 48,13$ & 78 & $123,84 \pm 43,13$ & 35,63 & $21,17-50,09$ & $0,000^{*}$ \\
\hline
\end{tabular}

${ }^{*}$ Bermakna $(p<0,05)$

Pediatrics (AAP), yaitu durasi menonton TV $\geq 2$ jam dan durasi menonton TV <2 jam, maka ditemukan 65\% kasus mempunyai durasi menonton TV $\geq 2$ jam dan $40 \%$ kontrol mempunyai durasi menonton $T V \geq 2$ jam. Dengan kata lain, anak yang menonton TV $\geq 2$ jam berisiko 3,3 kali ( $O R=.3,28$, 95\% Cl: 2,19-4,94) untuk menjadi obesitas dibandingkan anak yang menonton TV < 2 jam perhari (Tabel 7 dan Gambar 3). Sedangkan jika analisis dilakukan untuk mengukur besar risiko anak obes dan tidak obes di masing-masing wilayah Kota Yogyakarta dan Kabupaten Bantul diperoleh hasil bahwa anak di sekolah dasar Kabupaten Bantul memiliki peluang yang lebih tinggi untuk mengalami obesitas dengan durasi menonton TV $\geq 2$ jam perhari (Tabel 7).

Analisis dose-effect dilakukan untuk mengetahui hubungan peningkatan durasi menonton TV dari yang direkomendasikan oleh AAP dengan peningkatan peluang kejadian obesitas. Peluang kejadian obesitas meningkat lebih dari 2 kali lipat setiap penambahan 1 jam durasi menonton TV per hari (Tabel 8). 
Tabel 6. Peraturan orang tua dan durasi menonton TV pada anak

\begin{tabular}{|c|c|c|c|c|c|c|c|}
\hline \multirow{2}{*}{$\begin{array}{l}\text { Rata-rata durasi nonton TV } \\
\text { (menit/hari) }\end{array}$} & \multicolumn{4}{|c|}{ Peraturan orang tua } & \multirow[b]{2}{*}{$\begin{array}{c}\text { Mean } \\
\text { diff }\end{array}$} & \multirow[b]{2}{*}{$95 \% \mathrm{Cl}$} & \multirow[b]{2}{*}{$\mathbf{p}$} \\
\hline & $\mathbf{N}$ & $\begin{array}{c}\text { Ya } \\
\text { Mean } \pm \text { SD }\end{array}$ & $\mathbf{n}$ & $\begin{array}{c}\text { Tidak } \\
\text { Mean } \pm \text { SD }\end{array}$ & & & \\
\hline Anak sekolah dasar $(n=488)$ & 317 & $132,61 \pm 49,50$ & 171 & $146,55 \pm 48,54$ & $-13,94$ & $-23,10-(-4,77)$ & $0,002^{*}$ \\
\hline Obes $(n=244)$ & 147 & $146,96 \pm 50,64$ & 97 & $161,97 \pm 46,55$ & $-15,00$ & $-27,65-(-2,37)$ & $0,010^{*}$ \\
\hline Tidak obes $(n=244)$ & 170 & $120,20 \pm 45,08$ & 74 & $126,34 \pm 43,66$ & $-6,14$ & $-18,39-6,11$ & 0,162 \\
\hline
\end{tabular}

*Bermakna $(p<0,05)$

Tabel 7. Kategori durasi menonton TV dan risiko obesitas

\begin{tabular}{|c|c|c|c|c|c|}
\hline $\begin{array}{c}\text { Durasi nonton TVI } \\
\text { hari }\end{array}$ & $\begin{array}{c}\text { Obes }(n=244) \\
n(\%)\end{array}$ & $\begin{array}{c}\text { Tidak obes } \\
\begin{array}{c}(n=244) \\
n(\%)\end{array}\end{array}$ & $\begin{array}{c}\text { Total }(n=488) \\
n(\%)\end{array}$ & $\mathbf{p}$ & $\begin{array}{c}\text { OR } \\
(95 \% \mathrm{Cl})\end{array}$ \\
\hline \multicolumn{6}{|l|}{ Rata-rata sehari } \\
\hline $\begin{array}{l}\geq 2 \text { jam } \\
<2 \text { jam }\end{array}$ & $\begin{array}{l}187(60.52) \\
57(31.84)\end{array}$ & $\begin{array}{l}122(39.48) \\
122(68.16)\end{array}$ & $\begin{array}{l}179(100) \\
309(100)\end{array}$ & $0.000^{*}$ & $\begin{array}{c}3,28 \\
(2,19-4,94)\end{array}$ \\
\hline \multicolumn{6}{|l|}{ Kota Yogyakarta } \\
\hline $\begin{array}{l}\geq 2 \mathrm{jam} \\
<2 \mathrm{jam}\end{array}$ & $\begin{array}{c}125(75,3) \\
41(24,7)\end{array}$ & $\begin{array}{l}83(50,0) \\
83(50,0)\end{array}$ & $\begin{array}{l}208(100) \\
124(100)\end{array}$ & $0.000^{*}$ & $\begin{array}{c}3,05 \\
(1,87-4,99)\end{array}$ \\
\hline \multicolumn{6}{|l|}{ Kab. Bantul } \\
\hline $\begin{array}{l}\geq 2 \text { jam } \\
<2 \text { jam }\end{array}$ & $\begin{array}{l}62(79,5) \\
16(20,5)\end{array}$ & $\begin{array}{l}39(50,0) \\
39(50,0)\end{array}$ & $\begin{array}{l}101(100) \\
55(100)\end{array}$ & $0.000^{*}$ & $\begin{array}{c}3,87 \\
(1,81-8,41) \\
\end{array}$ \\
\hline
\end{tabular}

*Bermakna $(p<0,05)$

Tabel 8. Dose-effect durasi menonton TV dan odds ratio kejadian obesitas

\begin{tabular}{lccccc}
\hline $\begin{array}{c}\text { Rata-rata durasi nonton TV } \\
\text { (menit/hari) }\end{array}$ & $\begin{array}{c}\text { Obes } \mathbf{( n = 2 4 4 )} \\
\mathbf{n}(\%)\end{array}$ & $\begin{array}{c}\text { Tidak obes }(\mathbf{n}=244) \\
\mathbf{n}(\%)\end{array}$ & OR & p & 95\% Cl \\
\hline$<120$ & $57(31,84)$ & $122(68,16)$ & Ref. & & \\
$120-180$ & $116(54,98)$ & $95(45,02)$ & 2,61 & $0,000^{*}$ & $1,72-3,96$ \\
$>180$ & $71(72,45)$ & $27(27,55)$ & 5,63 & $0,000^{*}$ & $3,27-9,69$ \\
\hline
\end{tabular}

*Bermakna $(p<0,05)$

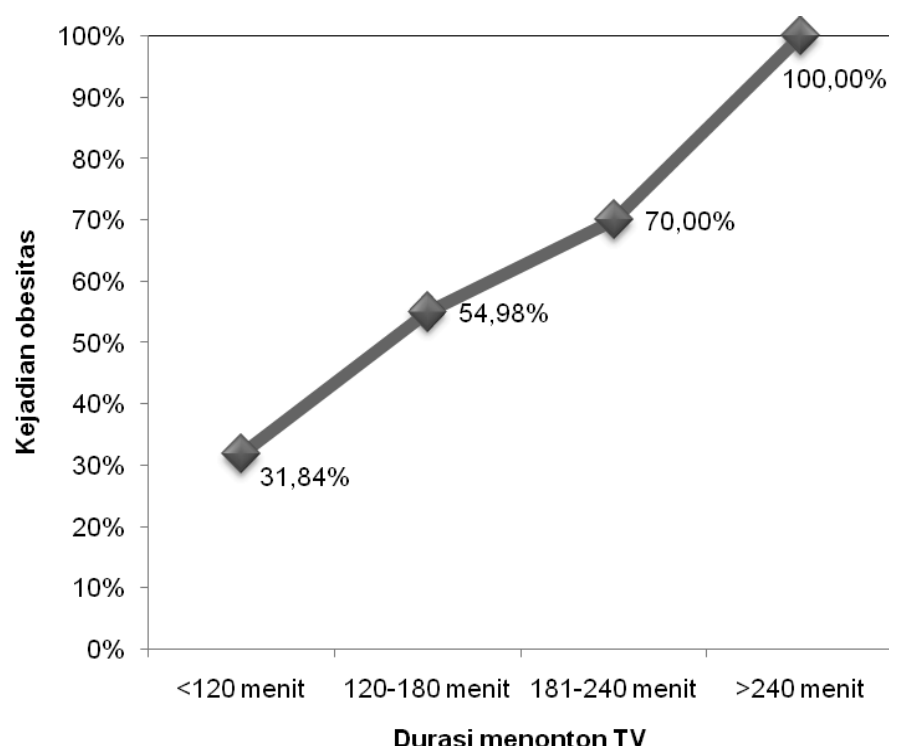

Gambar 3. Persentase kejadian obesitas berdasarkan durasi menonton TV

\section{Analisis multivariat kejadian obesitas dengan durasi menonton TV dan faktor lainnya}

Analisis multivariat dilakukan dengan menghubungkan beberapa variabel independen yang berdasarkan analisis bivariat memiliki nilai $p<0,25$. Variabel yang dimasukkan dalam analisis multivariat adalah durasi menonton TV, peraturan orangtua, jenis kelamin, jumlah TV, dan TV dalam kamar tidur anak (Tabel 9). Berdasarkan hasil analisis tersebut dapat diketahui bahwa dalam Model 2, peraturan orang tua tidak mengubah peluang kejadian obesitas yang diakibatkan oleh durasi menonton TV per hari pada anak sekolah dasar. Variabel jenis kelamin merupakan variabel yang secara signifikan mempengaruhi kejadian obesitas yang diakibatkan oleh durasi menonton TV dengan tingkat peluang untuk menjadi obesitas lebih besar pada anak laki-laki dibandingkan dengan anak perempuan.

Model 6 adalah model yang paling baik untuk menjelaskan kejadian obesitas dengan nilai $R^{2}$ paling besar dan nilai deviance terkecil. Dapat disimpulkan bahwa 7,6\% kejadian obesitas dalam penelitian ini dapat dijelaskan 
Tabel 9. Analisis regresi logistik hubungan durasi menonton TV dengan kejadian obesitas dikontrol variabel lainnya

\begin{tabular}{|c|c|c|c|c|c|c|}
\hline \multirow{3}{*}{ Variabel } & \multicolumn{6}{|c|}{ Kejadian obesitas } \\
\hline & Model 1 & Model 2 & Model 3 & Model 4 & Model 5 & Model 6 \\
\hline & $\begin{array}{c}\text { OR } \\
95 \% \mathrm{Cl} \\
\end{array}$ & $\begin{array}{c}\text { OR } \\
95 \% \mathrm{Cl}\end{array}$ & $\begin{array}{c}\text { OR } \\
95 \% \mathrm{Cl}\end{array}$ & $\begin{array}{c}\text { OR } \\
95 \% \mathrm{Cl}\end{array}$ & $\begin{array}{c}\text { OR } \\
95 \% \mathrm{Cl} \\
\end{array}$ & $\begin{array}{c}\text { OR } \\
95 \% \mathrm{Cl} \\
\end{array}$ \\
\hline \multicolumn{7}{|l|}{ Durasi nonton TV } \\
\hline $\begin{array}{l}\geq 2 \mathrm{jam}^{1} \\
<2 \mathrm{jam}^{1}\end{array}$ & $\begin{array}{c}3,28^{*} \\
(2,22-4,83)\end{array}$ & $\begin{array}{c}3,29^{*} \\
(2,23-4,85)\end{array}$ & $\begin{array}{c}3,39^{*} \\
(2,29-5,03)\end{array}$ & $\begin{array}{c}3,27^{*} \\
(2,21-4,83)\end{array}$ & $\begin{array}{c}3,24^{*} \\
(2,19-4,79)\end{array}$ & $\begin{array}{c}3,29^{*} \\
(2,21-4,90)\end{array}$ \\
\hline \multicolumn{7}{|c|}{ Peraturan orangtua } \\
\hline $\begin{array}{l}\text { Tidak } \\
\mathrm{Ya}^{1}\end{array}$ & & $\begin{array}{c}1,36 \\
(0,92-2,01)\end{array}$ & & & & $\begin{array}{c}1,28 \\
(0,86-1,91)\end{array}$ \\
\hline \multicolumn{7}{|l|}{ Jenis kelamin } \\
\hline $\begin{array}{l}\text { Perempuan } \\
\text { Laki-laki }^{1}\end{array}$ & & & $\begin{array}{c}0.54^{*} \\
(0.37-0.79)\end{array}$ & & & $\begin{array}{c}0.56^{*} \\
(0,38-0,82)\end{array}$ \\
\hline \multicolumn{7}{|l|}{ Jumlah TV } \\
\hline $\begin{array}{l}\geq 2 \text { unit }^{1} \\
<2 \text { unit }^{1}\end{array}$ & & & & $\begin{array}{c}0,69 \\
(0,42-1,13)\end{array}$ & & $\begin{array}{c}0,81 \\
(0,47-1,38)\end{array}$ \\
\hline \multicolumn{7}{|c|}{ TV dalam kamar tidur } \\
\hline $\begin{array}{l}\text { Ya } \\
\text { Tidak }^{1}\end{array}$ & & & & & $\begin{array}{c}1,32 \\
(0,88-1,97)\end{array}$ & $\begin{array}{c}1,20 \\
(0,78-1,86)\end{array}$ \\
\hline $\mathrm{R}^{2}(\%)$ & 5.6 & 5.6 & 7.0 & 5,9 & 5,8 & 7,6 \\
\hline $\mathrm{n}$ & 488 & 488 & 488 & 488 & 488 & 488 \\
\hline Deviance & 638,52 & 638,26 & 628,68 & 636,44 & 636,7 & 624,52 \\
\hline
\end{tabular}

*Bermakna $(p<0,05)$

${ }^{1}$ referensi/acuan

dengan faktor durasi menonton TV $\geq 2$ jam per hari, tidak adanya peraturan orang tua, jenis kelamin anak, jumlah TV, dan TV dalam kamar tidur anak.

\section{BAHASAN}

\section{Karakteristik subjek penelitian}

Hasil analisis variabel karakteristik subjek penelitian menunjukkan bahwa variabel jenis kelamin laki-laki dan perempuan berbeda bermakna terhadap kejadian obesitas. Karakteristik tumbuh kembang anak yang diduga menjadi salah satu faktor risiko yang memungkinkan anak perempuan memiliki risiko yang lebih besar untuk menjadi obesitas dibandingkan anak laki-laki, tidak sejalan dengan penelitian ini. Hal ini sesuai dengan hasil survei dalam Riskesdas Provinsi DIY tahun 2007 (2) serta penelitian di Medan tahun 2008 (9) yang mengidentifikasi lebih banyak kejadian obesitas pada anak laki-laki dibandingkan anak perempuan. Usia anak yang dalam penelitian ini berkisar antara 6-12 tahun belum merupakan tahap perkembangan saat terjadi perubahan komposisi tubuh dan pencirian tumbuh kembang remaja putra dan putri.

Variabel pendidikan dan pekerjaan ibu, pendidikan dan pekerjaan ayah, pengeluaran rumah tangga, dan jumlah anggota keluarga tidak menunjukkan perbedaan bermakna antara kelompok obes dan tidak obes $(p>0,05)$. Namun demikian, penelitian lain menyatakan bahwa latar belakang orang tua, dalam hal ini adalah pendidikan dan penghasilan, mempengaruhi kejadian obesitas anak melalui perbedaan perilaku sehat pada anak. Orang tua dengan tingkat pendidikan yang rendah memiliki pengetahuan yang kurang baik tentang pola hidup sehat seperti makanan sehat, frekuensi, dan jumlah makanan yang baik untuk dikonsumsi. Sebaliknya, orang tua dengan penghasilan yang rendah memiliki keterbatasan dana untuk dapat membeli makanan dengan nilai gizi yang baik dan untuk berolahraga (10). Selain itu, terdapat hubungan yang berkebalikan antara status bekerja ibu dan status bekerja ayah terhadap kejadian obesitas pada anak. Ayah yang bekerja akan menurunkan kemungkinan obesitas pada anak, akan tetapi status bekerja ibu akan meningkatkan kemungkinan obesitas pada anak (11). Meningkatnya kejadian obesitas dari anak dengan ibu yang bekerja kemungkinan akibat kurangnya pengawasan ibu terhadap pola makan dan aktivitas anak, sedangkan dalam penelitian ini tidak ditemukan adanya perbedaan kejadian obesitas pada anak dengan ibu yang bekerja dan atau dengan ayah yang bekerja.

Peraturan orang tua yang dinilai dalam variabel ini adalah peraturan dari orang tua anak tentang lamanya waktu yang diperbolehkan untuk menonton TV dalam sehari serta acara-acara yang boleh ditonton oleh anak dan dihubungkan dengan kejadian obesitas pada anak. Perbedaan yang bermakna antara kelompok obes dan tidak obes dalam hal peraturan orang tua menunjukkan bahwa anak yang obes memiliki lebih banyak kebebasan dalam menggunakan televisi, yakni lama durasi menonton televisi dan acara yang ditonton. Penelitian lain juga menemukan adanya hubungan yang bermakna antara 
peraturan orang tua dengan durasi menonton TV kurang dari atau $\geq 2$ jam per hari pada anak (5).

Mekanisme yang diduga memperantarai kejadian obesitas melalui menonton TV yaitu kebiasaan mengkonsumsi makanan pada saat menonton TV, tidak dapat dibuktikan dalam penelitian ini. Hasil dalam penelitian tidak menunjukkan adanya hubungan kebiasaan makan pada saat menonton TV, frekuensi sarapan, makan siang dan makan malam sambil menonton TV dengan kejadian obesitas pada anak $(p>0,05)$. Hubungan antara menonton TV dengan konsumsi makanan mungkin bukan pada frekuensi namun pada jenis dan jumlah asupan. Anak dari keluarga yang memiliki kebiasaan menonton TV di waktu makan utamanya akan mengkonsumsi lebih sedikit buah dan sayur serta akan lebih banyak mengkonsumsi makanan dan minuman tinggi kalori dibandingkan anak dari keluarga yang menjadikan waktu makan dan menonton TV sebagai aktivitas yang terpisah (12). Selain itu, kebiasaan mengkonsumsi camilan pada saat menonton TV berhubungan dengan meningkatnya asupan kalori secara keseluruhan dan asupan kalori dari lemak (13).

\section{Pola menonton televisi}

Stasiun TV dan genre acara. Tidak ada perbedaan preferensi stasiun TV dan genre acara yang disukai oleh anak obes dan tidak obes dalam penelitian ini. Hal ini menunjukkan bahwa baik anak obes maupun tidak obes memiliki kemungkinan yang sama untuk terpapar iklan makanan yang ditayangkan selama acara yang ditonton pada stasiun TV tersebut. Selanjutnya, durasi menonton TV yang akan membedakan tingkat paparan iklan pada anak. Penelitian yang dilakukan di Amerika Serikat menunjukkan bahwa sekitar $50 \%$ dari waktu untuk iklan yang ditampilkan pada program anak merupakan iklan makanan $(14,15)$ dan 9 dari 10 iklan makanan yang ditayangkan adalah produk makanan yang tidak sehat (15).

Waktu puncak dan durasi menonton TV. Perbedaan waktu puncak menonton TV antara weekdays dan Sabtu dengan hari Minggu disebabkan oleh perbedaaan aktivitas anak, yaitu pada hari weekdays dan Sabtu anak masih dalam aktivitas rutin bersekolah, sehingga waktu yang memungkinkan anak untuk menonton TV adalah pada malam hari seusai belajar/mengerjakan tugas. Sebaliknya, hari Minggu adalah hari libur dan pagi hari adalah waktu saat sebagian besar stasiun TV menayangkan program yang diperuntukkan bagi anak-anak.

Rata-rata durasi menonton TV pada anak obes lebih tinggi dibandingkan anak tidak obes dan melebihi yang direkomendasikan oleh AAP. Selain itu, rata-rata durasi menonton TV pada weekends juga lebih panjang dibandingkan dengan weekdays. Hal ini disebabkan anak sedang libur sekolah, sehingga waktu luang tersebut diisi dengan menonton televisi. Untuk mengisi waktu luang anak di hari libur, diperlukan peran orang tua untuk mengikutsertakan anak dalam kegiatan yang lebih bermanfaat untuk kesehatannya misalnya dengan mengajak anak berenang, mengikutkan dalam kegiatan kursus, atau melibatkan anak dalam aktivitas harian di rumah seperti merapikan rumah dan taman. Lamanya durasi yang digunakan orang tua yang melakukan aktivitas fisik yang sehat akan mempengaruhi durasi aktivitas fisik pada anak (16).

Durasi menonton TV yang lebih panjang pada anak di sekolah dasar Kabupaten Bantul mungkin disebabkan oleh adanya perbedaan akses terhadap jenis media elektronik pada anak-anak di sekolah dasar Kota Yogyakarta dan Kabupaten Bantul. Anak-anak perkotaan memiliki lebih banyak pilihan pada media elektronik selain televisi, misalnya komputer, tablet, handphone, playstation dan media lainnya. Penggunaan media-media ini seperti halnya penggunaan televisi, merupakan bentuk kegiatan sedentari dan anak-anak yang menghabiskan lebih banyak waktu dalam penggunaan media ini memiliki peluang yang lebih besar untuk mengalami overweight dibandingkan anakanak yang tidak (17). Penggunaan media selain televisi tidak diteliti dalam penelitian ini, namun ada kemungkinan anak di perkotaan memiliki durasi yang sama atau bahkan mungkin lebih panjang dalam hal penggunaan media berbasis layar dibandingkan dengan anak di desa, hanya jenis media yang digunakan saja yang berbeda.

\section{Peraturan orang tua dan durasi menonton TV}

Penelitian ini menunjukkan adanya pengaruh peraturan orang tua mengenai menonton TV terhadap durasi menonton TV pada anak. Meskipun perbedaan durasi ini tidak terlalu besar namun secara statistik dinyatakan bermakna. Hal ini sejalan dengan penelitian lain yang menyatakan bahwa peraturan orang tua berhubungan dengan durasi menonton TV pada anak (5).

Orang tua adalah figur yang sangat berpengaruh pada anak dalam membentuk pola perilaku dan sebagai model yang ditiru. Perilaku orang tua, dalam hal ini adalah kebiasaannya menonton TV berhubungan dengan durasi menonton TV pada anak yang $\geq 2$ jam per hari (5). Saat perintah tidak diberlakukan dengan tegas dan tidak dibarengi dengan contoh, maka akan sulit bagi anak untuk mematuhinya. Hal ini yang mungkin dapat menjelaskan masih tingginya durasi menonton TV pada anak obes yang mendapat peraturan dari orang tua.

\section{Durasi menonton TV dan risiko obesitas}

AAP merekomendasikan untuk menonton televisi tidak lebih dari 1 hingga 2 jam per hari (4) sebagai upaya meminimalkan dampak negatif dari paparan media elektronik terhadap kesehatan. Analisis rata-rata durasi menonton televisi yang dikategorikan menurut rekomendasi dari AAP memberikan hasil beda bermakna antara anak 
obes dan tidak obes, yaitu anak yang menonton TV $\geq 2$ jam per hari memiliki peluang 3,28 kali lebih besar untuk menjadi obesitas sebelum dikontrol oleh variabel lain.

Analisis dose effect yang dilakukan untuk mengetahui peningkatan durasi menonton TV terhadap peluang kejadian obesitas menunjukkan bahwa setiap peningkatan durasi menonton TV 1 jam dari yang direkomendasikan oleh AAP, maka peluangnya untuk menjadi obesitas adalah 2 kali lebih besar. Hal ini menunjukkan bahwa setiap peningkatan durasi menonton TV akan memperbesar peluang kejadian obesitas pada anak.

Durasi menonton TV yang panjang pada anak dapat mengakibatkan obesitas dan akan berdampak pada status kesehatannya di masa yang akan datang. Setiap peningkatan durasi menonton TV 2 jam per hari akan meningkatkan risiko obesitas sebesar $23 \%$ dan untuk mengalami diabetes tipe 2 sebesar $14 \%$ pada wanita dalam penelitian kohor yang dilakukan selama 6 tahun di Amerika Serikat (18).

Anak di sekolah dasar di Kabupaten Bantul yang menonton TV $\geq 2$ jam per hari memiliki peluang yang lebih besar untuk menjadi obesitas dibandingkan anak di sekolah dasar di Kota Yogyakarta. Hal ini mungkin disebabkan oleh adanya perbedaan jenis media yang digunakan oleh anak di Kabupaten Bantul dan di Kota Yogyakarta. Diperlukan penelitian lebih lanjut yang mengukur durasi penggunaan seluruh media berbasis layar yang tidak terukur dalam penelitian ini untuk mengetahui peluang kejadian obesitas dari durasi penggunaan media berbasis layar tersebut.

\section{Analisis multivariat kejadian obesitas dengan durasi menonton TV dan faktor lainnya}

Hasil analisis multivariat dengan pemodelan menunjukkan bahwa durasi menonton TV memiliki korelasi bermakna dengan kejadian obesitas pada anak setelah dikontrol oleh variabel-variabel lain. Dari keseluruhan variabel yang diikutkan dalam pemodelan analisis multivariat, hanya variabel jenis kelamin yang berkorelasi bermakna dengan kejadian obesitas yang disebabkan oleh durasi menonton TV yang $\geq 2$ jam per hari. Namun demikian, jenis kelamin bukan merupakan variabel confounding ataupun modifikasi sebab nilai OR durasi menonton TV terhadap kejadian obesitas setelah dikontrol oleh jenis kelamin tidak menunjukkan perubahan yang bermakna. Hasil ini menunjukkan bahwa variabel jenis kelamin merupakan faktor risiko obesitas pada anak dengan OR sebesar 0,54 pada anak perempuan dan jenis kelamin laki-laki sebagai referensi.

Alasan yang mungkin dapat menjelaskan mengapa anak laki-laki lebih berisiko untuk menjadi obesitas dibandingkan anak perempuan dengan durasi menonton TV $\geq 2$ jam per hari adalah adanya budaya patriarki di kalangan masyarakat. Orang tua memberikan lebih banyak tugas rumah tangga kepada anak perempuan dibandingkan anak laki-laki, sehingga mereka memiliki lebih banyak waktu luang. Anak laki-laki dapat menggunakan waktunya untuk melakukan kegiatan yang menarik dan bersantai (19). Selain itu, anak laki-laki hampir 2 kali lebih banyak yang lebih memilih menonton TV dan bermain game daripada beraktivitas fisik dibandingkan anak perempuan (5). Dengan demikian, meskipun anak perempuan menonton TV $\geq 2$ jam per hari, namun mereka juga tetap melakukan aktivitas fisik yang lebih banyak dibandingkan anak lakilaki sehingga peluang untuk menjadi obesitas menjadi lebih kecil. Dengan kata lain, secara tidak langsung jenis kelamin menjadi faktor risiko obesitas dengan sebelumnya mempengaruhi tingkat aktivitas fisik pada anak.

\section{KESIMPULAN DAN SARAN}

Tiga stasiun TV favorit pada anak sekolah dasar adalah stasiun TV yang menayangkan banyak acara anak dengan genre program acara yang paling banyak digemari adalah kartun, sinetron, dan film. Waktu puncak menonton TV pada anak sekolah dasar adalah malam hari atau magrib hingga waktu tidur malam pada weekdays dan hari Sabtu, sedangkan pada hari Minggu adalah pagi hingga pukul 12 siang. Ada pengaruh peraturan dari orang tua tentang menonton TV terhadap durasi menonton TV pada anak. Anak yang tidak mendapat peraturan orang tua memiliki durasi menonton TV yang lebih panjang dibandingkan anak yang mendapat peraturan dari orang tua, namun hal ini tidak menurunkan risiko kejadian obesitas pada anak yang diakibatkan oleh durasi menonton TV. Anak obes memiliki durasi menonton TV lebih panjang daripada anak yang tidak obes dengan selisih rata-rata durasi menonton adalah 30 menit per hari dengan odds ratio kejadian obesitas 3,29 kali lebih besar pada anak dengan rata-rata durasi menonton TV $\geq 2$ jam per hari setelah mengendalikan faktor lain.

Berdasarkan hasil tersebut yang menunjukkan bahwa durasi menonton $\mathrm{TV} \geq 2$ jam sebagai faktor risiko obesitas, maka diperlukan peran orang tua untuk mendampingi anak dan memberikan peraturan yang tepat tentang penggunaan televisi untuk mengurangi panjangnya durasi aktivitas sedentari dan keterpaparan anak pada iklan makanan. Penelitian selanjutnya, perlu dilakukan pengumpulan data asupan makanan yang dikonsumsi selama menonton TV maupun asupan total untuk mengetahui kontribusi asupan makanan selama menonton TV terhadap kejadian obesitas pada anak.

\section{RUJUKAN}

1. Prentice AM. The Emerging Epidemic of Obesity in Developing Countries. Int J Epidemiol 2006;35:93-9.

2. Kementerian Kesehatan RI. Riset Kesehatan Dasar (Riskesdas) 2007. Jakarta: Badan Penelitian dan 
Pengembangan Kesehatan Kementerian Kesehatan $\mathrm{RI} ; 2008$.

3. Kementerian Kesehatan RI. Riset Kesehatan Dasar (Riskesdas) 2010. Jakarta: Badan Penelitian dan Pengembangan Kesehatan Kementerian Kesehatan $\mathrm{RI} ; 2011$.

4. American Academy of Pediatrics Committee on Public Education. Children, Adolescents, and Television. Pediatr 2001;107(2):423-6.

5. Salmon J, Timperio A, Telford A, Carver A, Crawford D. Association of Family Environment with Children's Television Viewing and With Low Level of Physical Activity. Obes Res 2005;13:1939-51.

6. Halford JCG, Gillespie, Jane B, Victoria B, Pontin EE, Dovey TM. Effect of Television Advertisement for Foods on Food Consumption in Children. Appetite 2004;42:221-5.

7. Harris JL, Bargh JA, Brownell KD. Priming Effects of Television Food Advertising on Eating Behavior. Health Psychol 2009;28(4):404-13.

8. Dennison BA, Erb TA, Jenkins PL. Television Viewing and Television in Bedroom associated with Overweight Risk among Low-Income Preschool Children. Pediatr 2002;109:1028-35.

9. Simatupang MR. Pengaruh Pola Konsumsi, Aktivitas Fisik dan Keturunan terhadap Kejadian Obesitas pada Siswa Sekolah Dasar Swasta di Kecamatan Medan Baru Kota Medan. [Tesis]. Medan: Sekolah Pascasarjana Universitas Sumatera Utara; 2008.

10. Romani AQ. Parental Socioeconomic Background and Child Behaviour. Soc Indic Res 2013;DOI 10.1007/ s11205-013-0281-3.
11. Benson LJ. The Role of Parental Employment in Childhood Obesity. [Disertasi]. USA: University of Maryland; 2010.

12. Coon KA, Goldberg J, Rogers LB, Tucker KL. Relationship Between Use of Television During Meals and Children's Food Consumption Pattern. Pediatr 2001;107:e7.

13. Gore SA, Foster JA, DiLilli VG, Kirk K, West DS. Television Viewing and Snacking. Eating Behavior 2003;4:399-405.

14. Gantz W, Schwartz N, Angelini JR, Rideout V. Food for Thought: Television Food Advertising to Children in the United States. A Kaiser Family Foundation Report; 2007.

15. Batada A, Seitz MA, Wootan MG, Story M. Nine out of 10 Food Advertisements Shown during Saturday Morning Children's Television Programming Are for Foods High in Fat, Sodium, or Added Sugars, or Low in Nutrients. J Am Diet Assoc 2008;108:673-8.

16. Bonke J, Greve J. Children's Health-Related LifeStyles: How Parental Child Care Affects Them. Rev Econ Household 2012;10:557-72.

17. The Kaiser Family Foundation. The Role of Media in Childhood Obesity. Available from www.kff.org.

18. Hu FF, Li TY, Colditz GA, Willet WC, Manson JE. Television Watching and Other Sedentary Behaviors in Relation to Risk of Obesity and Tipe 2 Diabetes Mellitus In Woman. JAMA 2003;289:1785-91.

19. Carvalho MJ. Gender and Children's Time Use. Available from: http://www.lume.ufrgs.br/bitstream/ handle/10183/538/000339102. pdf?sequence=1 . 